\title{
SOIL MOISTURE AND ITS INFLUENCE ON PASTURE PRODUCTION IN THE WAIKATO
}

\author{
J. A. BaArs and J. D. Coulter \\ Ruakura Agricultural Research Centre, Hamilton, and \\ N.Z. Meteorological Service, Wellington
}

\section{Abstract}

The occurrence and distribution of soil moisture deficit days in the Waikato were determined for 43 years (1930-73) by calculating day-to-day changes in soil moisture for four soil types. The calculations were based on actual daily rainfall data and an estimate of mean daily potential evapotranspiration. Seasonal distributions of the number of deficit-days are given.

On three soil types with 87,102 and $117 \mathrm{~mm}$ of available soil moisture there were more than 20 such days in at least 15 of the 43 years. January to April inclusive are the "high-risk months".

A significant negative correlation was obtained between the number of deficit-days and pasture production from a non-irrigated, "rate-of-growth" trial, such that 20 deficit-days gave a $21 \%$ reduction in expected annual pasture production (below that expected with no deficit-days).

\section{INTRODUCTION}

Rickard (1960) and Rickard and Fitzgerald (1970) found a significant negative correlation between non-irrigated pasture production at Winchmore and the seasonal number of days of "agricultural drought". In these studies agricultural drought was defined as existing when the moisture content of the soil in the root zone is at wilting point or below, and was either measured by frequent grevimetric determinations or estimated from meteorological data.

It was decided to carry out a similar investigation on four different soil types in the Waikato and, owing to a lack of longterm gravimetric soil moisture determinations, the simpler water balance approach was adopted. Changes in the water content of the root zone are followed taking account of estimated potential evapotranspiration and actual rainfall on the basis that daily transpiration requirements are met from, the root zone and that any surplus rainfall is discharged either as deep drainage or surface runoff. Because the main source of variation is the rainfall, average monthly values calculated by the Thornthwaite 
method may be used to estimate the daily potential evapotranspiration or water need. A day is called a (soil moisture) "deficit-day" when the available scil moisture as calculated (plus any rainfall) is insufficient to meet that day's water need.

A deficit-day does not have to be a day of agricultural drought as the method is rather crude and based on several 'assumptions that are cnly approximations:

(1) It is assumed that the soil moisture deficit is always re$\mathrm{p}$ !enished before runoff cccurs.

(2) It is assumed that water is lost at the estimated potential evaporation rate irrespective of the actual root zone water content provided that this is greater than wilting point.

(3) It is assumed that daily evapotranspiration is the same for each day of the month until wilting point is reached regardless of the current weather. (Variations in rainfall from day to day are allowed for.)

For the Waikato, in the relevant months (September to March), the Thornthwaite method results in a lower estimation of mean monthly potentiall evspotranspiration (and hence of number of deficit-days) as compared with values based either on the Penman method or on tank evaporation data (Coulter, 1973b). April to August have low evaporation rates and, usually, high rainfall and do not influence the estimates. The Thornthwaite method was used to determine the occurrence and distribution of soil moisture deficit-days over the longest possible period.

Coulter (1973a) used an arbitrary allowance of $75 \mathrm{~mm}$ for available soil water capacity to assess the New Zealand climate with respect to the general water requirements of vegetation. On this basis, at Ruakura Agricultural Research Centre, soil moisture deficit-days (i.e., days when accumulated soil moisture losses exceeded $75 \mathrm{~mm}$ ) were found to occur in about $85 \%$ of growing years (July-June), averaging 24 days per year. They occurred from December to April inclusive, most often in January, February and March on average 6 out of 10 months had some deficitdays.

Maunder (1972) established significant correlation's 'between monthly dairy production and indices based on the number of deficit-days in preceding months, calculated for $75 \mathrm{~mm}$ available soil water (Coulter, 1973a). These correlations form the basis for predictions of dairy production currently made on an experimental basis by the New Zealand Meteorological Service for the New Zealand Dairy Board. 
Gradwell (1968) reported plant available water figures for four important soil types in the Waikato. His figures show Hamilton clay loam can store $87 \mathrm{~mm}$ of plant available water (between field capacity and wilting point) in a depth of $76 \mathrm{~cm}$, Horotiu sandy loam $102 \mathrm{~mm}$, Ohaupo silt loam $117 \mathrm{~mm}$ and Te Kowai silt loam $177 \mathrm{~mm}$. The B and C 'horizons of these four soils are the source of these differences. Grange et al. (1939) noted that a dry summer lessened the growth of clover on Hamilton clay loam and Horotiu sandy loam until the following summer, and that pastures on Hamilton clay loam were the first to be affected by dry weather. Annett (19.51) noted that Hamilton clay loam on the hilltops was the first to suffer from drought followed by Horotiu sandy loam, lastly the lower lying Te Kowhai silt loam.

To make these calculations more realistic for the Waikato, available water figures for four different soil types (Gradwell, 1968) and rainfall data for the years 1930 to 1973 from the meteorological station at Ruakura Agricultural Research Centre were used to calculate daily changes in available water and numbers of deficit-days over 43 years.

It must be emphasized that these are preliminary results of a continuing study which will be more fully reported in the future.

\section{RESULTS}

A summary of the seasonal frequency of deficit-days at Ruakura is given in Table 1 and the average monthly distribution in Table 2. No deficit-days occurred in winter and spring. Summer months are December to February and autumn, March to May. The values used for maximum available soil moisture capacity are given (in $\mathrm{mm}$ ) in Table 1 for each soil type.

These data show Te Kowhai silt loam as being much less susceptible to limiting soil moisture deficits than the other three soil types. January to April inclusive, especially February and March, are "high-risk" months relative to other months.

Hamilton clay loam is the first to suffer from serious deficits and further implications are considered for this soil type.

\section{IRRIGATION NEEDS}

Hamilton clay loam has $87 \mathrm{~mm}$ available water per $76 \mathrm{~cm}$ of soil, but grass growth is progressively depressed after available soil water levels go below $62 \mathrm{~mm}$ (Hopewell, 1958). Using calculated water deficits over the period 1930-73 nominal irriga- 
TABLE 1: SEASONAL FREQUENCY OF DEFICIT-DAYS

Ruakura 1930-73

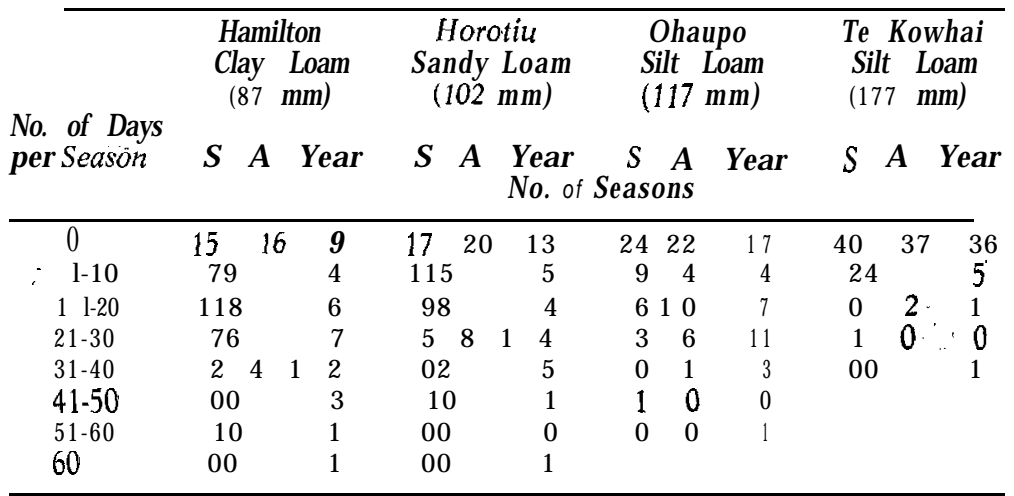

$\mathrm{S} \overline{\sqrt{\mathrm{r}}}$ Summer; $\mathrm{A}=$ Autumn

i.

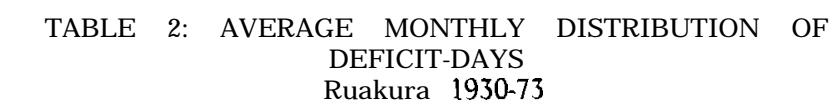

\begin{tabular}{|c|c|c|c|c|}
\hline Month: & $\begin{array}{l}\text { Hamilton } \\
\text { Clay Loam }\end{array}$ & $\begin{array}{c}\text { Horofiu } \\
\text { Sandy Loam } \\
\text { Average No. of }\end{array}$ & $\begin{array}{c}\text { Ohaupo } \\
\text { Silt Loam } \\
\text { Days per Month }\end{array}$ & $\begin{array}{l}\text { Te Kowhai } \\
\text { Silt Loam }\end{array}$ \\
\hline Dec. & 0 & 0 & 0 & 0 \\
\hline Jan. & 4 & 2 & 1 & 1 \\
\hline Feb. & 8 & 6 & 4 & 1 \\
\hline Mar. , , & 8 & 7 & 6 & 0 \\
\hline Apr:..? & 2 & 2 & 2 & 0 \\
\hline May & 0 & 0 & 0 & 0 \\
\hline Todal ans & 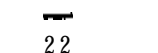 & $\overline{17}$ & - & - \\
\hline
\end{tabular}

tion needs for the summer-autumn period were calculated with, soil moisture utilization limited to $25 \mathrm{~mm}$ below field capacity i.e., the sum of irrigations at a deficit of $25 \mathrm{~mm}$. No allowance was made for efficiency of application.

Table 3 gi ves the average annual irrigation needs and the range of variation for years classified according to the number of deficit-days, as defined in the previous section. (The number of years in each class, from Table 1, is repeated here for reference, along with its percentage frequency.)

The average irrigation need was $148 \mathrm{~mm}$, and in 22 of the 43 years there was a nominal irrigation requirement of at least $150 \mathrm{~mm}$ (and in 34 years at least $100 \mathrm{~mm}$ ) according to this simple water balance study. 
SOIL MOISTURE AND PASTURES

TABLE 3: DISTRIBUTION OF ANNUAL IRRIGATION NEEDS OF HAMILTON CLAY LOAM WITH SOIL MOISTURE DEFICIT

LIMITED TO $25 \mathrm{~mm}$

Ruakura $1930-73$

\begin{tabular}{ccccc}
\hline $\begin{array}{c}\text { No. of } \\
\text { Deficit-days }\end{array}$ & $\begin{array}{c}\text { No. of } \\
\text { Year }\end{array}$ & $\begin{array}{c}\% \text { of } \\
\text { Years }\end{array}$ & $\begin{array}{c}\text { Average } \\
\text { Irrigation Needed } \\
(\mathbf{m m})\end{array}$ & $\begin{array}{c}\text { Range } \\
(\mathbf{m m})\end{array}$ \\
\hline $\mathbf{0}$ & $\mathbf{9}$ & 21 & 92 & $65-133$ \\
$1-10$ & + & 10 & 120 & $91-154$ \\
$11-20$ & 6 & 4 & 142 & $115-156$ \\
$21-30$ & 7 & 16 & 158 & $134-201$ \\
$31-40$ & 12 & 28 & 171 & $141-230$ \\
$41-50$ & 3 & 7 & 206 & $186-234$ \\
$51-60$ & 1 & 2 & 210 & \\
60 & 1 & 2 & 246 & \\
\hline
\end{tabular}

EFFect of Restricted SOIL MoIsture Supply on Production

Pasture production data from a pasture growth rate trial on: Hamilton clay loam at Rukuhia Soil Research Station for the period 1954-70 were used to calculate the effect of moisture deficit on pasture growth. The pasture composition was perennial ryegrass (Lolium perenne) and white clover (Trifolium repens) with Poa triviulis, Poa annua, cocksfoot (D actylis glomerata), browntop (Agrostis tenuis), sweet vernal (Anthoxanthum odoratum) and Yorkshire fog (Holcus lanatus). The r a t e of growth technique as described by Lynch (1966) was used. Cuts were at fortnightly intervals.

Annual pasture production for the 16 years together with the total numbers of soil moisture deficit-days in each season and year were used to calculate the following regression equations in which $P$ is the production in $\mathrm{kg}$ of dry matter per ha and $D$ is the number of deficit-days calculated from daily rainfall data at Rukubia Soil Research Station for appropriate time intervals. Ruakura Agricultural Research Centre daily rainfall data gave similar results.

$\begin{array}{llll}\text { For annual totals: } & P=12642-130.4 D & r=-0.83 \\ \text { For summer : } & P=3464-86.90 & r=-0.68 * \\ \text { For 'autumn : } & P=2182-37.10 & r=-0.55^{\prime \prime} \\ \text { For summer and autumn: } & P=5915-78.60 & r=-0.79 *\end{array}$

"Significant at the 5\% level only, 
In an average year with 22 deficit-days, pasture production IS approximately $23 \%$ below that expected with soil moisture not limited. Winter and spring production are not influenced by summer and autumn periods of soil moisture deficit.

Other production data were obtained from an experiment sampled for 16 years at approximately 25-day intervals (Noble, 1972). The regression equation cvbtained was:

$$
P=15387-109.3 D \quad r=-0.71^{*}
$$

\section{DISCUSSION}

During et al. (1970), who summarized data from the rate of growth trial at Rukuhia Soil Research Station, found that in the Waikato January to April inclusive are responsible for much of the large fluctuation in annual pasture production. Climatic data over 43 years are consistent with this conclusion in that deficitdays occur at this time of year and also fluctuate widely from year to year.

These data give an estimate of deficit-days and irrigation requirements which is probably too low for several reasons:

( 1) The Thornthwaite method probably underestimates summer potential evapotraaspiratien and number of deficit-days.

(2) Mitchell and Kerr (1966) found water usage from pasture much in excess of potential evapotranspiration as customarily calculated.

(3) On Hamilton clay loam the pasture must have ample moisture in the top $10 \mathrm{~cm}$ of soil and soil moisture below this depth is of little use to it (Annett and Noble, 1950; Annett, 195 1). The data of Gradwell (1968) indicate that the top $10 \mathrm{~cm}$ of this soil holds about $25 \mathrm{~mm}$ of available water (between $200 \mathrm{~cm}$ water tension and wilting point), but that the amount of "readily available water" is appreciably less (about $10 \mathrm{~mm}$, if the range of availability is taken as between 100 and $1000 \mathrm{~cm}$ water tension). Hence it would probably be necessary to apply more water than we have calculated.

Using daily rainfall figures and multiplying the daily tank evaporation figures by a factor of 0.9 to arrive at potential evapotranspiratioa, Weeda (1965 and pers. comm.) applied on average $307 \mathrm{~mm}$ (allowing for efficiency of application) over the period 1953-64 in a trial on this soil type. This is about 1.9 times 
our calculated figures over this period and probably gives a more accurate indication of practical water needs.

On average, total annual dry matter production was raised by $33 \%$ using irrigation over this period. Weather records from 1930-73 suggest that grass growth would benefit considerably from irrigation in 34 of 43 years $(80 \%)$, in which the minimum actual irrigation requirement very likely would be 190 (1.9 $x$ 100) $\mathrm{mm}$. Compared with other districts, the Waikato has been defined as carrying only a medium risk of low production in summer. It has a relatively good climate for dairying. Nevertheless, in at least 17 of the 43 years studied $(39 \%)$ the number of deficit-days exceeded 30 on Hamilton clay loam. It indicates that pasture growth cannot give sustained feed supplies over the summer-autumn period and that under livestock systems irrigation and/or supplementary feeds have to be considered to maintain production in the Waikato, especially if carrying capacities are raised.

\section{ACKNOWLEDGEMENTS}

We are grateful to W. C. Weeda for making irrigation data available.

\section{REFERENCES}

Annett, H. E., 1951: N.Z. Il Agric., 82: 397.

Annett, H. E.; Noble, P. F., 1950: N.Z. Il Agric., 80: 517

Coulter, J. D., 1973a: N.Z. Il Hydrol., 12 (2): 83.

Coulter, I. D., 1973b: N.Z. Dep. sci. industr. Res. Inf. Ser., 96: 38.

During, C.; Mitchell, K. J.; Lancaster, R. J., 1970: New Zealand Beef Production, Processing and Marketing. (Ed. A. G. Campbell). N.Z. Inst. Agric. Sci. p. 235.

Gradwell, M. W., 1968: N.Z. $f l$ agric. Res., II: 631.

Grange, L. I. et al., 1939: N.Z. Dep. sci. industr. Res. Bull., 76, 35 pp. Hopewell, H. G., 1958: N.Z. Il A gric., 96: 106.

Lynch, P. B., 1966: N.Z. Dep. Agric. Bull., 399, 154 pp.

Maunder, J. W., 1972: N.Z. M et. Serv. Tech. N ote 208 (unpubl.).

Mitchell, K. J.; Kerr, J. R., 1966: Agronomy I., 58: 5.

Noble, P. F., 1972: N.Z. Il agric. Res., 15: 676.

Rickard, D. S., 1960: N.Z. /l agric. Res., 3: 432.

Rickard, D. S.; Fitzgerald, P. D., 1970: Proc. 10th Int. Grassld Congr.: 487.

Weeda, W. C., 1965: N.Z. /l agric. Res., 8: 1060. 